office as president-elect on January 1, when Dr. Harry N. Holmes, head of the Department of Chemistry at Oberlin College, became president, succeeding Prof. William L. Evans, head of the Department of Chemistry at the Ohio State University. In addition to his contributions to the development of synthetic rubber, Dr. Frolich is best known for his work on transformation and chemical utilization of hydrocarbons, high-pressure gas reactions, catalysis and applied colloid chemistry. On September 9,1940 , he and his research associates read the first technical report on the discovery of butyl rubber, made from petroleum.

Dr. Frolich was born in Christiansand, Norway, in 1899, and graduated from the Norwegian Institute of Technology in 1921. He received the degree of master of science from the Massachusetts Institute of Technology in 1923, and the degree of doctor of science from the same institution in 1925. He was assistant chemist at the Norwegian Institute of Technology during 1919-1921, instructor at Christiansand Business College during 1921-1922, and AmericanScandinavian Foundation fellow at the Massachusetts Institute of Technology during 1922-1923. $\mathrm{He}$ served as assistant in the Massachusetts Institute of Technology Research Laboratory of Applied Chemistry during 1925-1927. He became assistant director of the Laboratory in 1927 and was advanced to associate professor in 1929, the year he joined the staff of the Standard Oil Development Company. He was awarded the Grasselli Medal in 1930 for outstanding achievement in chemistry, particularly in the field of high-pressure reaction of gases.

\section{Centenary of Flammarion}

Camille Flammarion, the French astronomer whose books found readers in all parts of the globe, was born on February 25, 1842, at the small town of Montigny-le-Roi, in Haute-Marne. The son of a shopkeeper, he was educated at a church school and then began work in an engraver's office. His merits being brought to the notice of Leverrier, at the age of sixteen he was given a place in the Paris Observatory, where he stayed four years. At the age of twenty he published his first book, "The Plurality of Inhabited Worlds", the forerunner of his "The Marvels of the Heavens", "Popular Astronomy", "The Planet Mars", "Astronomy for Amateurs" and many others. His "Popular Astronomy" when first published in French in 1879 was awarded the Montyon Prize of the Paris Academy of Sciences and was selected for use in the French public libraries. Through an admirer of his writings, Flammarion, in 1883, came into possession of a small château and park at Juvisy-sur-Orge and he built an observatory there. The previous year he had founded the review, $L '$ Astronomie, and five years after that, in 1887, he started the Société Astronomique de France. His death took place at Juvisv, June 4, 1925, when he had reached the age of eighty-four.

\section{University of Sheffield}

THe University of Sheffield has received a bequest of $£ 1,200$ by the late Mr. L. N. Ledingham to found a bursary fund for students in the Department of Metallurgy, to be called "The Ledingham Bursary Fund".

The Council decided that because of the close association of the Department of Pharmacology with clinical teaching and because the professor of pharmacology is responsible for the teaching of therapeutics, the Department of Pharmacology should in future be given the title of Department of Pharmacology and Therapeutics, and that the professor of pharmacology should be given the title of professor of pharmacology and therapeutics.

\section{Announcements}

DR. R. L. WATERFIELD has been awarded the Jackson-Gwilt Medal and Gift of the Royal Astronomical Society "for his general contributions to astronomy, and in particular for his photographic work on eclipses and comets and his visual observations of planets". The Medal will be presented at the annual general meeting to be held on April 10.

THE King has approved the following awards of the Polar Medal in silver for good services with the Oxford University Arctic Expedition to North East Land in 1935 and 1936 : Lieut. A. R. Glen; Instr.

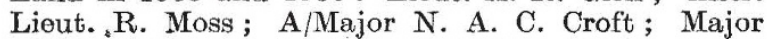
A. S. T. Godfrey; Capt. A. B. Whatman; R. A. Hamilton, D. B. Keith, A. Dunlop-Mackenzie, J. W. Wright.

The Edison Medal for 1941 has been awarded by the American Institute of Electrical Engineers to Prof. J. B. Whitehead, director of the school of engineering of the Johns Hopkins University, "for his contributions to the field of electrical engineering, his pioneering and development in the field of dielectric research, and his achievements in the advancement of engineering education".

Tre Committee of the Athenæum has elected the following gentlemen, under the provisions of Rule II of the Club, which empowers the annual election by the Committee of a certain number of persons of distinguished eminence in science, literature, or the arts, or for their public services: Air Chief Marshal Sir Wilfrid Rhodes Freeman, Vice-Chief of the Air Staff; Prof. E. H. Minns, emeritus professor of archæology, University of Cambridge; Prof. P. H. Winfield, Rouse Ball professor of English law, University of Cambridge.

Dr. H. Spencer Joneis, Astronomer Royal, will deliver the Symons Memorial Lecture of the Royal Meteorological Society on March 18. He will speak on "The Atmosphere of the Planets".

The following appointments in the Colonial Service have recently been made : Mr. J. C. Alley, veterinary officer, Nigeria; Captain L. Nicholls (conservator of forests), deputy chief conservator of forests, Nigeria.

WE have received a copy of the 1941 edition of the Official Directory of the British Chemical Plant Manufacturers' Association, containing a directory of members, a classified list of products and services, a list of proprietary and trade names and marks, and other information. A copy of this Directory will be issued gratis to inquirers interested in the purchase of British chemical plant on application to the Association, 166 Piccadilly, London, W.1.

Erratum. In the article "Feeding Post-War Europe", by Dr. Geoffrey Bourne, Nature, February 14, p. 182, the amount of vitamin $C$ required by Great Britain should read "700 tons" and not "30 tons" as printed.

We regret that it has not yet been possible to issue the Index to vol. 148 of Nature. An announcement will be made as soon as the date of publication is fixed. 